\title{
Problem of human rights violations during the migrant crisis in Europe
}

\author{
A. S. Matveevskaya ${ }^{1}$, S. N. Pogodin², Wang Juntao ${ }^{2}$ \\ ${ }^{1}$ St. Petersburg State University, \\ 7-9, Universitetskaya nab., St. Petersburg, 199034, Russian Federation \\ ${ }^{2}$ Peter the Great St. Petersburg Polytechnic University, \\ 29, Politechnicheskaya ul., St. Petersburg, 195251, Russian Federation
}

For citation: Matveevskaya A. S., Pogodin S. N., Wang Juntao. Problem of human rights violations during the migrant crisis in Europe. Vestnik of Saint Petersburg University. Philosophy and Conflict Studies, 2021, vol. 37, issue 3, pp. 508-515. https://doi.org/10.21638/spbu17.2021.311

The aim of this study was to identify how Europe's migrant crisis affected human rights in the European Union. It focuses on the observance of fundamental human rights in the context of migration. Violations directly related to migrants and refugees are considered. Human rights law is the most universal and general branch of law on which all other laws rely. The issue of observance of these rights becomes even more critical in regard to forced migration. While these rights are guaranteed to 'all members of the human family', there are conditions under which universally recognized human rights should be protected and justified with particular care. Obviously, inalienable human rights may easily be compromised when it comes to prisoners or refugees. Ensuring human rights in the European Union is based on a variety of international treaties, EU regulations and internal legislation of the member countries which have adopted high standards in the field of human rights protection. With regard to the right to asylum as an essential component of the human rights law, it can be stated that an unprecedented level of integration has enabled the EU to establish a pan-European asylum system based on the standards enshrined in the 1951 Geneva Convention and the 1967 Additional Protocol, as well as to gain considerable experience in dealing with migrants and refugees and ensuring their inalienable rights. In general, legislation in this area is constantly being improved and it reflects modern challenges and threats. The member countries of the European Union are on the way to developing a unified approach to migration policy and international protection issues. However, the asylum system is imperfect and has numerous gaps, which have been repeatedly mentioned by experts and members of the academic community even before the migrant crisis began.

Keywords: human rights, migrant crisis, EU regulations, migrants, refugees.

Migration policy has always been an important part of the policy of European countries, and many of them have pursued a policy of attracting foreign labor in the post-war period. The problem of illegal entry of migrants is also a traditional one. At the same time, the unprecedented nature of the migrant crisis, the beginning of the acute phase of which falls on 2015, is noted in many scientific publications, media and statements made by politicians [1]. More than 1,800,000 migrants and refugees arrived in Europe in 2015 [2]. This surge in the number of migrants and the European Union countries' inability to effectively

(C) St. Petersburg State University, 2021 
and rapidly take measures that would reduce the pressure on destination countries, as well as the ensuing social and political crisis, is referred to as 'Europe's migrant crisis'.

Let us highlight some features of the migrant crisis. The mixed nature of the migration flows is one of the biggest challenges in dealing with refugees. By the mixed migration flow we imply a situation when potential refugees are moving around together with economic and other categories of migrants. Mainly Syrian citizens arrived in Europe during the migrant crisis (more than 350 thousand applications were submitted for refugee status in 2015), they were followed by citizens of Afghanistan (about 180 thousand applications), Iraqi citizens (about 120 thousand applications), then citizens of Nigeria and Pakistan (approximately 50 thousand applications) [3]. While for Syrian citizens the percentage of approved applications was roughly 90 percent in 2015, it was markedly lower for the citizens of other countries [4]. This is because the European countries responsible for processing applications found that the reasons that prompted these people to arrive in Europe were beyond humanitarian necessity. Thus, the mixed nature of migration to Europe in recent years has become one of the greatest obstacles to regulate the migration flow, since this required an even more individual approach to each applicant, complicated the situation in reception centers, and led to the fact that forced migrants were treated as violators of the law.

The fact that the migrant crisis has affected the European Union countries to varying degrees has become another characteristic feature of the crisis. There were almost 11 million external migrants in the EU by 2010, as well as some 5-7 million illegal migrants. As for such a category of migrants as refugees, it amounted to 1.4 million people or $9 \%$ of the total number of recognized refugees worldwide [5]. Most of them were under the international protection of Germany (594,269 people), Great Britain (238,150 people) and France $(200,687$ people). More than $1,800,000$ migrants and refugees arrived in the European Union countries illegally in 2015 alone. Greece and Italy have become the countries experiencing the greatest migration pressure, as Greece received about 850 thousand refugees in 2015, while Italy about 150,300 people [6]. Interestingly, Hungary, although closing its borders in 2015, had the largest number of refugees per share of the population, i. e., 29,959 people, that is 1,800 refugees per 100,000 people [7]. The policy of solidarity led to the fact that the richest European countries accepted more people than they expelled under the Dublin Regulation, meaning they redistributed the number of refugees among other member countries of the European Union. Additionally, this distribution was uneven. Germany received about 1,600,000 asylum applications from 2014 to 2017, Italy about 380,000, France about 330,000, Sweden less than 300,000, and the rest of the European countries received much fewer applications [3]. The level of positive decisions on refugee status also varies significantly. In 2015, France approved only $27 \%$ of applications, compared with $42 \%$ of positive decisions made by Italy and $80 \%$ of positive decisions made by the Netherlands [8]. At the same time, the largest number of positive decisions in 2015 were made by Germany, Sweden, Italy and France. However, none of the European countries were among the top ten countries by the end of 2015 that hosted the largest number of refugees [9]. We may state that such a distribution of the load was maintained throughout the entire crisis.

As we have already noted, the main flow of migrants arrived in Italy and Greece, which led to the inability of the border control system and the asylum system of these countries to handle such a burden. Italy and Greece received 154,000 and 885,000 un- 
documented migrants in 2015, but only 83,000 and 11,000 new asylum applications were registered, respectively [10]. Conditions prevailing in the refugee reception centers did not meet the accepted standards; the number of people in the camps could be twice or more than the camp's capacity. This literally forced refugees to live on the streets. It turned out that neither a single country nor the European Union as a whole were prepared for such a crisis situation.

The European migrant crisis has clearly shown that the rights assigned to a person may be questioned in a situation of forced migration. Unlike the regional institute of refugee rights, the single institution of 'asylum' was developed relatively recently in the European Union. Moreover, serious shortcomings of the system were noted even in the years preceding the crisis in the EU countries. It seems natural that this new institution, which is still in the formative stage in many respects, will inevitably show all its shortcomings and weaknesses under the influence of the crisis situation.

EU countries were unprepared for the situation when approximately two million refugees and migrants arrived in the $\mathrm{EU}$ in just one year. It is only natural that countries such as Greece, Italy and Hungary, which did not cope with migration flows in previous years, could not cope with them when it increased many times over. The existing human rights problems only worsened in such circumstances, and cases of violations were revealed again [11].

Greece is still one of the most common examples in the situation. The number of asylum seekers staying on the island of Lesbos at the height of the crisis exceeded thrice the camp's capacity, and more than twice the camp capacity on the islands of Samos and Chios. Much effort has been made to improve living conditions for migrants during the migrant crisis: the EU has invested heavily in infrastructure (electricity, water communications, wastewater systems), training sufficient qualified medical and psychological caregivers, and special efforts have been made to improve the living conditions of the most vulnerable groups of migrants [12]. Since 2015, Greece has received 525 million euros in emergency assistance in addition to the 561 million previously allocated for its national programs for 2014-2020, and this has paid off. Thus, the UN High Commissioner for Human Rights welcomed the efforts of Greece aimed at respecting human rights, refraining from imprisonment and expulsion, in his speech in 2016 [13]. However, he still found living conditions in the camps unsatisfactory. Migrants who wished to escape life in overcrowded camps were unable to leave the country due to restrictions imposed by a number of countries, such as Macedonia, Slovenia, Croatia, Slovakia, Hungary, the Czech Republic and Serbia. The measures they have taken have increased the pressure on Greece and put the migrants' lives and safety at risk.

All these violations are equally related to Italy, which is also suspected of violating the procedure of the Dublin Regulation. Thus, in one of the Italian regions bordering Austria and Slovenia, there is an unusually high rate of processing refugee applications and their expulsion to the designated countries even without informing the refugees that such a decision has been made with regard to them and without giving them an opportunity to confirm possible family ties in Italy [14].

In times of crisis, violations of another key human right, the right to seek asylum, have become more apparent, despite the fact that it was enshrined in numerous international conventions and European regulations. EU countries are preventing migrants from entering their territory by using measures such as strengthening border controls 
and enacting stricter legislation. A number of countries send police or military forces to the border to physically stop migrants from crossing it. Hungary is a textbook example, as it has installed a barbed wire fence along its border with the Czech Republic to keep migrants out of its territory. While European countries are fighting illegal migration, more than 90 percent of asylum seekers arrive in the EU illegally [15]. Compliance with the Geneva Convention on Refugees is not possible in the absence of a legal way of entering the EU. Under European law, a refugee is a person who has applied for refugee status. If migrants are unable to enter the country, they are automatically deprived of the opportunity to request refugee status. One of Hungary's most radical decisions was the introduction of a criminal term for illegal entry into the country, which was in direct contravention of Article 31 of the Refugee Convention [16]. According to Article 31, "The Contracting States shall not impose penalties, on account of their illegal entry or presence, on refugees '...' provided they present themselves without delay to the authorities and show good cause for their illegal entry or presence" [17].

Failure to assist migrants arriving from across the Mediterranean is an even more significant violation of human rights. Thus, the death of a significant number of migrants has become one of the most striking characteristics of the migration crisis. The majority of bodies of migrants who died on the Mediterranean migration route remain unidentified [18]. The period from January to August 2015, when more than 2,400 people died, was the most tragic one in this sense [19]. In total, 3,784 people died on this route in 2015. In 2016, the number of deaths on the route only increased in comparison with 2015 and reached 5,143 people [20]. However, the fact that European countries refuse to rescue migrants arriving by this route is a violation of international law, European law and even the law of the sea. In addition, there is no doubt that almost all deaths have occurred due to the lack of an alternative, safer way to enter the EU.

Similar to before 2015, most migrants are placed in detention centers upon arrival in the EU. This contradicts the European Convention on Human Rights, which prohibits unlawful detention. It also violates the Refugee Convention, Article 26 of which states that "Each Contracting State shall accord to refugees lawfully in its territory the right to choose their place of residence and to move freely within its territory subject to any regulations applicable to aliens generally in the same circumstances" [17]. The problem, however, is that many European countries exceed the permissible period of detention.

The UN High Commissioner for Human Rights has repeatedly pointed out that children are among the most vulnerable in Europe, as they are deprived of access to medicine and are most at risk of becoming victims of human trafficking. Ideally, the children's rights are the most protected type of human rights. However, as a result of the migrant crisis, children often end up in the same centers and camps as adults, where they become victims of violence [21]. Asylum seekers have not only the right to seek asylum, but the right to minimum social and economic rights as well. The right of children to education is worth noting in this context. Under EU legislation, obtaining a free secondary education is not only a right, but also an obligation, and this right is confirmed by the International Convention on the Rights of the Child [22]. However, there is no need to speak of the respect for these rights in the context of the European migrant crisis, when even the basic rights to security and respect for human dignity have not been granted [23].

Women are in an equally difficult situation. Reports by Amnesty International and Human Rights Watch describe numerous cases in which young girls and women have 
been the victims of harassment and violence by both men living with them in camps and by police and border guards. The living conditions in the camps also contributed to the increased danger. Women in the camps were reportedly afraid to visit showers and latrines because they were shared between men and women. There were cases of women being harassed who, as a result, tried to remain awake at night [24].

The expulsion of migrants to third countries, often Libya, is also a very worrying trend. Although the EU-Turkey agreement is controversial but legal from the point of view of law, the return of migrants to Libya has repeatedly been criticized by non-profit human rights organizations [25]. The cooperation of European countries with the Libyan government within the framework of the African Union - EU - UN three-party format to release migrants from detention, assist them in their voluntary return and evacuate especially vulnerable people is currently one of the priorities of political regulation in the sphere of migration. As the migration flow to Spain increased, the European Union strengthened cooperation with Morocco; and despite the fact that this country does not currently have any asylum system, 232 million euros have already been invested in the program [26]. This measure is mainly aimed at combating illegal migration, but it may well lead to the situation when forced migrants will not get access to the proper procedure.

The situation with human rights violations has only worsened during the migrant crisis, both due to the increased number of arrivals and the fault of a number of anti-crisis measures taken by the European Union. European countries have taken measures contrary to international and European law in their attempt to prevent migrants from entering their territory, regardless of their intentions [27]. It is clear that even basic human rights that have long become part of customary law are no longer guaranteed to everyone in times of crisis. Generally, the most serious violations occur in countries that do not respect human rights as a whole, but even more democratic countries meet only a fraction of their obligations in a crisis. Self-security was undoubtedly the top priority for the EU countries, and migrants were perceived at best as a problem to be solved and as a migration burden to be shared, rather than as people whose rights should be guaranteed. Based on the comparison of the situation before and during the crisis, it may be concluded that human rights violations have been caused not so much by the increased flow of migrants as by imperfect legislation in this area and the unpreparedness of the European Union asylum system, as well as by the significant lack of solidarity between member countries at such a critical time when the system needed to be urgently reformed. To date, there is a tendency to improve the human rights situation, which can be explained both by the fact that the migration flow is decreasing and that the EU countries have learned a certain lesson from the 20152017 situation. Furthermore, they have adapted to the arrival of large numbers of migrants and refugees. The problem of how the situation will develop in terms of ensuring the right to reunification, protection against discrimination and exercise of second-generation rights by migrants, including the right to integration, is crucial at the moment.

The given work allows us to conclude that the 'migrant crisis' is more of a human rights crisis and a crisis of pan-European values, as evidenced by the fact that the massive influx of migrants has resulted in political confrontation between some Member States of the European Union. Politicization of the migration process may now be observed, which leads to the fact that the focus is shifting to the perception of migration as a 'background criminal phenomenon' from ensuring and protecting life, health, safety and other basic rights of refugees. One of the major human rights concerns is that the exercise of funda- 
mental rights is still subject to the legal status of a person. Thus, even refugees, a category that under the international law may expect mandatory international protection, find themselves in a certain legal vacuum before they obtain official status.

There is no doubt that the EU asylum and migration systems require structural reforms. One of the ways of reform could be the creation of a legal route for the refugees from the Middle East and African countries to enter the EU. This would help to avoid human casualties and violation of basic human rights, and it would also improve control over people entering. However, reforming the pan-European asylum system will require greater solidarity among the countries involved. Currently, the EU countries cannot undertake radical changes in this area in their attempt to preserve pan-European unity, and as a result, the rights of migrants and refugees are under a potential threat. Moreover, the obvious contradiction between the right of an EU member country to independently decide on the duration of stay for foreign nationals on its territory and the EU directives aimed at increasing solidarity in this area jeopardizes the ability of the EU member countries to ensure effective protection of human rights in respect to those persons who were forced to leave their native countries.

\section{References}

1. Iag'ia, V.S. and Matveevskaya, A.S. (2019), On the migration policy of the European Union, in Aktual'nye problemy mirovoi politiki, vol. 9, St. Petersburg: St. Petersburg University Press, pp. 242-251. (In Russian)

2. Official website of the FRONTEX. Available at: https://frontex.europa.eu/ (accessed: 12.04.2021).

3. Official website of the BBC News. Available at: https://www.bbc.com/news/world-europe (accessed: 20.04.2021).

4. Latest asylum trends EASO. Available at: https://www.easo.europa.eu/latest-asylum-trends (accessed: 23.03.2021).

5. Official website of the European Parliamentary Research Service. Available at: http://www.europarl. europa.eu/ (accessed: 19.04.2021).

6. Irregular Migrant, Refugee Arrivals in Europe Top One Million in 2015. Available at: https://www. iom.int/news/irregular-migrant-refugee-arrivals-europe-top-one-million-2015-iom (accessed: 25.03.2021).

7. Akopian, E. S. and Kozhina, V.O. (2016), Migration crisis in Europe, Vestnik mezhdunarodnogo instituta ekonomiki i prava, no. 2, 23, pp. 26-31. (In Russian)

8. Chiron, P. (2017), European migration policies, at the frontier of the law, Institut de relations internationales et stratégiques, p.11. Available at: https://www.iris-france.org/wp-content/uploads/2018/07/Obshuma-Chiron-Politiques-migratoires.pdf (accessed: 25.03.2021).

9. Official website of The UN Refugee Agency. Available at: https://www.unhcr.org (accessed: 25.03.2021).

10. Official website of the Eurostat News Release. Available at: https://ec.europa.eu/eurostat (accessed: 30.03.2021).

11. Matveevskaya, A.S. and Pogodin, S.N. (2018), Integration of migrants as a way to diminish proneness to conflict in multinational communities, Vestnik of Saint-Petersburg university. Philosophy and conflict studies, vol. 34, is. 1, pp. 108-114. https://doi.org/10.21638/11701/spbu17.2018.110.

12. Communication from the Commission to the European Parliament, the European Council and the Council managing migration in all its aspects: progress under the European agenda on migration COM $798 \mathrm{fi}$ nal (2018). Available at: https://eur-lex.europa.eu/resource.html?uri=cellar:e4f17910-fc7a-11e8-a96d01aa75ed71a1.0021.02/DOC_1\&format=PDF (accessed: 27.03.2021).

13. Official website of the UN Office of the High Commissioner for Human Rights. Available at: https:// ohchr.org/ (accessed: 27.03.2021).

14. The Dublin system in 2017. AIDA. Available at: https://asile.ch/wp/wp-content/uploads/2018/05/ aida_2017update_dublin.pdf (accessed: 27.03.2021).

15. Moreno, V. (2018), Humanitarian Visas: Legal Aspects - European Added Value Assessment, European Parliament Research Service. Available at: https://www.europarl.europa.eu/RegData/etudes/ STUD/2018/621823/EPRS_STU(2018)621823_EN.pdf (accessed: 27.03.2021). 
16. Official website of Asylum Information database. Available at: https://www.asylumineurope.org (accessed: 15.04.2021).

17. Convention relating to the Status of Refugees (1951), The UN Refugee Agency. Available at: http:// unhcr.ru/fileadmin/files/docs/Documents/pdf (accessed: 18.04.2021). (In Russian)

18. Death by region of origin. Available at: https://missingmigrants.iom.int/region/mediterranean (accessed: 20.04.2021).

19. Marenich, M.N. (2015), Current problems of refugee's rights and problems of migration control in the European Union, Nauchnoe soobshchestvo studentov XXI stoletiia. Gumanitarnye nauki. pp. 17-22. Available at: https://sibac.info/studconf/hum/xxxvii/43784 (accessed: 27.04.2021). (In Russian)

20. Ghailani, D. (2017), Europe facing the migration crisis: migrants' rights sacrificed on the security altar, in Bilan social de l'Union européenne 2017, European Trade Union Institute (ETUI) and Observatoire Social Européen (OSE), pp. 53-75.

21. Initial assessment report: Protection Risks for Women and Girls in the European Refugee and Migrant Crisis. Available at: https://www.unhcr.org/569f8f419.pdf (accessed: 15.04.2021).

22. Convention on the Rights of the Child (1989). Available at: https://www.un.org/ru/documents/decl_ conv/conventions/childcon.shtml (accessed: 18.04.2021). (In Russian)

23. Official website of European Union Agency for fundamental rights. Available at: https://fra.europa. eu/sites/default/files/fra_uploads/fra-2019-beyond-the-peak-migration-annual-review-2018_en.pdf (accessed: 20.04.2021).

24. Official website of Amnesty International. Available at: https://www.amnesty.org/en/latest/news/2016/01/ female-refugees-face-physical-assault-exploitation-and-sexual-harassment-on-their-journey-through-europe/ (accessed: 15.04.2021).

25. Country report - Immigration Detention in Libya: "A Human Rights Crisis". Available at: https:// ec.europa.eu/neighbourhood-enlargement/sites/near/files/eu-morocco-factsheet.pdf (accessed: 17.04.2021).

26. Official website of European Commission. Available at: https://ec.europa.eu/neighbourhood-enlargement/sites/near/files/eu-morocco-factsheet.pdf (accessed: 20.04.2021).

27. Matveevskaya, A., Solovyeva, V., Ermolina, M. and Pogodin, S. (2021), The crisis of the multiculturalism policy in Sweden, Springer Geography, pp. 48-62. https://doi.org/10.1007/978-3-030-58263-0_5.

Received: September 18, 2020

Accepted: June 25, 2021

Authors'information:

Anna S.Matveevskaya - PhD in Geographic Sciences, Assistant Professor; a.matveevskaya@spbu.ru Sergei N.Pogodin - Dr. Sci. in History, Professor; pogodin56@mail.ru

Wang Juntao — PhD in Political Sciences, Assistant Professor; juntao2013@yandex.ru

\section{Проблема нарушения прав человека в период миграционного кризиса в Европе}

А. С. Матвеевская ${ }^{1}$, С. Н. Погодин ${ }^{2}$ Ван Цзюньтао 2

${ }^{1}$ Санкт-Петербургский государственный университет,

Российская Федерация, 199034, Санкт-Петербург, Университетская наб., 7-9

${ }^{2}$ Санкт-Петербургский политехнический университет Петра Великого,

Российская Федерация, 195251, Санкт-Петербург, Политехническая ул., 29

Для цитирования: Matveevskaya A.S., Pogodin S.N., Wang Juntao. Problem of human rights violations during the migrant crisis in Europe // Вестник Санкт-Петербургского университета. Философия и конфликтология. 2021. Т. 37. Вып. 3. С. 508-515.

https://doi.org/10.21638/spbu17.2021.311

Целью данного исследования стало выявление того, как европейский миграционный кризис сказался на соблюдении прав человека в Европейском Союзе. При этом исследование посвящено в первую очередь проблеме соблюдения основных прав человека 
в условиях миграции, то есть нами будут рассматриваться нарушения, касающиеся непосредственно мигрантов и беженцев. Права человека является наиболее универсальной и общей отраслью права, на которую опираются все остальные. В контексте вынужденной миграции вопрос соблюдения данных прав становится еще более критичным. Несмотря на то, что эти права гарантированы «всем членам человеческой семьи», существуют условия, когда повсеместно признанные права человека необходимо защищать и обосновывать особенно тщательно. В ситуации, когда речь идет о заключенных или о беженцах, очевидные, неотъемлемые права человека могут легко оказаться под угрозой. В Европейском Союзе обеспечение прав человека базируется на множестве международных договоров, нормативных актов ЕС и внутреннем законодательстве стран-участников, которые переняли высокие стандарты в области защиты прав человека. Что касается столь важной составляющей права прав человека, как право на убежище, можно констатировать, что беспрецедентный уровень интеграции позволил ЕС создать общеевропейскую систему предоставления убежища, основанную на стандартах, закрепленных в Женевской конвенции 1951 года и Дополнительном протоколе 1967 года, а также наработать значительный опыт по работе с мигрантами и беженцами и обеспечению их неотъемлемых прав. В целом законодательство в этой сфере постоянно совершенствуется и отражает современные вызовы и угрозы. Государствачлены Европейского Союза находятся на пути выработки единого подхода к миграционной политике и вопросам международной защиты. Однако система убежища несовершенна и имеет множество пробелов, о которых неоднократно говорили и эксперты, и члены академического сообщества еще до начала миграционного кризиса.

Ключевые слова: права человека, миграционный кризис, нормативные акты ЕС, мигранты, беженцы.

Статья поступила в редакцию 18 сентября 2020 г.; рекомендована в печать 25 июня 2021 г.

Контактная информация:

Матвеевская Анна Сергеевна - канд. геогр. наук, доц.; a.matveevskaya@spbu.ru Погодин Сергей Николаевич - д-р ист. наук, проф.; pogodin56@mail.ru Ван Цзюньтао - канд. полит. наук, доц.; juntao2013@yandex.ru 